\title{
HERPES OPHTHALMICUS*
}

\author{
BY \\ DORIS ROSE \\ Eastbourne
}

A woman aged 72 was admitted to St. Mary's Hospital, Eastbourne, on May 12, $\overrightarrow{0}$ 1952. She stated that several days previously she awakened with a violent head- $\overrightarrow{\vec{\omega}}$ ache extending over the right side of the head, followed next day by a vesicular $\omega$ rash on the right side of the forehead; 3 days later the eyelids on both sides $\frac{O}{\circ}$. became swollen.

\section{Examination}

Right Eye. There was an herpetic rash over the area of distribution of the first division of the right fifth nerve. There was oedema of both eyelids and ao yellow purulent discharge exuded between them. The upward and inward ${ }_{-}$ movements were defective. The pupil was dilated. The optic disc was blurred. $\infty$ There were haemorrhages along the retinal vessels in the region of the disc. $\frac{\mathbb{O}}{0}$ There was no projection of light. Temperature $101-2^{\circ} \mathrm{F}$. Pulse 80.

Left Eye.-Lower lid oedematous. Vision 6/24 uncorrected. Otherwise nothing abnormal found.

Diagnosis.-Right herpes ophthalmicus with optic neuritis and third nerve paresis.

General Condition.-Respiratory system normal. Blood pressure 150/90.

Progress (14.5.52) All movements of the right eye were very limited. Early iritis was 
(18.5.52) Paralysis of right third, fourth, and sixth cranial nerves.

Corneal oedema now obscured optic neuritis.

Anterior chamber deep. Raised tension continued. No pain.

Still no projection of light. Patient very ill.

(21.5.52) Eye painful for the first time. Tension still raised.

Anterior chamber deep. Pupil circular. No synechiae.

(22.5.52) Iridectomy.

(26.5.52) Report of $x$ ray of chest.

"There is some evidence of cardiac enlargement. The left side of the diaphragm is obscured. The appearances suggest a small amount of fluid at the left base. Both lungs show fairly well marked congestive changes. No evidence of infection."

(27.5.52) Blood Count: Total red cell count: 4,770,000 per c.mm.

Haemoglobin 96 per cent. (Haldane).

Colour index: 1.02 .

Total white cell count: 7,100 per c.mm.

74 per cent. mature polynuclear neutrophils $\quad \ldots \quad \ldots \quad 5,254$

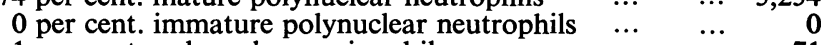

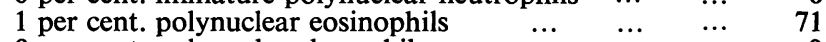

$\begin{array}{llllll}0 \text { per cent. polynuclear basophils } \ldots & \ldots & \ldots & \ldots & 0\end{array}$

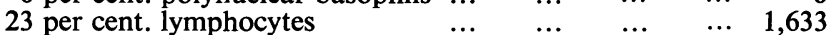

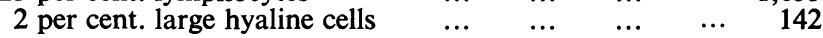

Dr. Taylor commented: "Anaemia is not present. A normal white cell count. There is nothing which gives a pointer to the origin of this pyrexia".

Again seen by Dr. Lester. Still no abnormal signs apart from the eye. Patient continued critically ill.

(31.5.52) Examination of Cerebrospinal Fluid.

About $4 \mathrm{ml}$. clear fluid showing a slight yellowish tinge were submitted.

Cells: 6 leucocytes per c.mm. A small number of erythrocytes noted.

Protein: 35 mgms. per cent.

Globulin: Nil.

Sugar: Normal.

Lange: 1111110000

(6.6.52) Cerebrospinal fluid, Wassermann reaction, and Kahn test negative.

(5.7.52) Right Eye.-No projection of light. Total ophthalmoplegia and pain persisted. Tension normal.

Left Eye.-Normal.

(8.7.52) Patient discharged from hospital.

(22.8.52) Considerable increase in ocular movements.

(17.10.55) All movements of the right eye were full, but otherwise the condition of the eye was unchanged.

\section{Conclusion}

This case commenced as a right herpes ophthalmicus. The complications were secondary glaucoma and total ophthalmoplegia. The secondary glaucoma was controlled by an iridectomy. The ophthalmoplegia eventually recovered. The patient was critically ill. My medical colleague, Dr. Lester, was unable to find any other inflammatory condition.

My thanks are due to Dr. Mark Lester for his help with this case. 